\title{
単ーサイズSクラスターの作成とラマン評価
}

\author{
小椋厚志 · E. C. HoneA* - C. A. MURRAY* - K. RAGHAVACHARI* \\ W. O. SPRENGER* • W. L. BrowN* \\ NECマイクロエレクトロニクス研究所 函305 つくば市御幸が丘 34 \\ *AT\&T Bell Laboratories
}

（1995年 7 月 12 日受理）

\section{Formation of Single Size Si Clusters and Their Evaluation by Raman Spectroscopy}

\author{
Atsushi Ogura, E. C. Honea*, C. A. Murray*, K. RaghavacharI*, \\ W. O. Sprenger* and W. L. Brown* \\ Microelectronics Res. Labs., NEC Corporation \\ 34 Miyukigaoka, Tsukuba, Ibaraki 305 \\ *AT\&T Bell Laboratories \\ 600 Mountain Avenue, Murray Hill, NJ07974-0636, USA
}

(Received July 12, 1995)

\begin{abstract}
レーザーアブレーション法で作製した Si クラスターを, 四重極質量分離器を用いて単一サイズに制御し, 同 時堆積した不活性分子マトリクス中に埋め込んで, 表面を $\mathrm{Ag}$ でコートしたサファイアプリズム基板上に堆積 した。表面プラズモン一ポラリトンラマン分光法で得た, 各サイズの Si クラスターからの振動モードを, 分子 軌道計算の結果と比較し構造解析を行った。その結果, $\mathrm{Si}_{4}$ は同一平面上の菱形, $\mathrm{Si}_{6}$ は圧縮された八面体, $\mathrm{Si}_{7}$ は上下をキャップされた正五角形であることが確認された。さらに，構造が既知である $\mathrm{Si}$ クラスターを出発材 料とする凝集過程を観察し，非晶質 Si に関する知見を得た。
\end{abstract}

\section{1. は じめに}

$\mathrm{Si}$ 原子 2 個から数百個で構成される Si クラスター は, $\mathrm{Si}$ 原子と固体 $\mathrm{Si}$ の中間のサイズをもち, 固体 $\mathrm{Si}$ と は異なった特有の構造と性質をもつ 産業を支える主要材料である Si では，技術的には個々 のデバイスのサイズを限りなく縮小する微細加工技術の 進展によって，その進歩を遂げてきた。現時点で単結晶 $\mathrm{Si}$ を加工して形成可能な最小サイズは, まだクラスター の領域からは程遠いものの, DRAM の容量部などで利 用されている多結晶 $\mathrm{Si}$ の粒径はクラスターの領域に近 づきつつある。また，近年多孔質 Si からの発光現象が 確認され, 微細な Si 粒子の物性の解明が望まれつつあ る。Siに代わりうる有力なデバイス材料が見当たらない 以上, 当分現在の $\mathrm{Si}$ 技術の延長線での技術開発が必要
であり, Si 材料の微細化の極限に出現するであろう現象 の確認を，現時点で行っておくことは有益である。

Si クラスターの性質は, 従来主に化学的な手法によ りその反応性やモビリティーが測定されている2 2 5)。し かしながら, その物理的な構造や電子構造の解明につな がる実験結果は乏しく，わずかにコンピュー夕計算によ る予測がなされているのみであった。 Si クラスターの物 理的な評価が困難であった第一の原因は, 文字どおり十 分な“物理量”を確保することが困難であったことに起 因し, 主に気相での評価が中心であった。本研究では, サイズを制御した Si クラスターを, 同時堆積した Ar, $\mathrm{Kr}, \mathrm{Xe}, \mathrm{N}_{2}$ などの不活性分子からなるマトリクス中に 埋め込むことで物理量を確保し, 表面プラズモン増強ラ マン分光法でその振動スペクトルを観測し, 計算との比 較で個々の構造を決定した。 


\section{2. 実 験}

\section{$2.1 \mathrm{Si}$ クラスターの堆積}

図 1 にSi クラスターの堆積/評価装置の構成を示す6)。 クラスター発生部では, $200 \mathrm{cc} / \mathrm{min}$ の $\mathrm{He}$ フロー中を $\mathrm{Si}$ ロットが回転・上下し, XeClエキシマレーザー $(200 \mathrm{~Hz}$, 〜20mJ, 10ns) を照射し, laser ablation で得た Si 原子 は, $\mathrm{He}$ の存在で衝突が加速され $\mathrm{Si}$ クラスター $\left(\mathrm{Si}_{n}\right)$ が 形成される。備え付けられた電子銃から $1 \mathrm{keV} に$ 加速さ れた電子がクラスターのイオン化を助長する。得られた

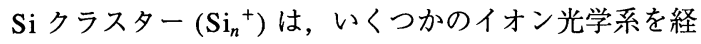
て, 四重極質量分離器の入口にフォーカスされる。所望 の単一サイズに制御された Si クラスターは, 中性分子 の污染を避けるために2 度曲げられた後, 最終段で減速 されて基板上に堆積される。堆積エネルギーの典型的な 値は $25 \mathrm{eV}$ とした。

サファイアを半円柱状のプリズムに加工した基板は, 平らな面に表面プラズモンの発生源となる $\mathrm{Ag}$ が堆積さ れていて, 液体 $\mathrm{He}$ の連続供給が可能なクライオスタッ トに固定されて, クラスターの堆積および測定中は約 15Kに冷却されている。さらに, クラスター堆積と同時 に Arなどのガスが基板に吹き付けられ多結晶マトリク スが同時堆積されて，サイズ制御されたクラスターがマ トリクス中に分離固定される。基板直下には熱フィラメ ントを用いた低エネルギー電子線源がセットされ，クラ スターイオンを中性化する。20３0分ごとにモニター したイオン電流は 100 800pA 程度であり, 堆積後に真 空外に取り出して行った RBS 測定の結果スポットサイ ズは 1 〜 $3 \mathrm{~mm}$ であり, 1〜4 時間の堆積で 1〜3 分子層
程度のクラスター量が得られることを確認した。イオン 電流の測定と RBS 測定の対比で得られたクラスターの 堆積速度に応じて, レーザー干渉法で補正したマトリク スの堆積速度を調整することで, 所望のクラスター密度 および分布が得られる。Siクラスターは Ag 表面のプラ ズモンが強く励起される領域 $(700 \sim 1500 \AA)$ に配置し, さらに光学定数を整える目的と測定中のクラスターを污 染から守る目的で数ミクロンのマトリクスがキャップさ れている。

\section{2 表面增強ラマン測定}

図2に，表面増強ラマンで用いた光学系の概略図を示 す。励起光にはArイオンレーザーを用い, ラインフィ ルターおよびスペースフィルターを通過した励起光は, レンズで集光され試料上では幅約 $100 \mu \mathrm{m}$, 長さ $2 \mathrm{~mm}$ 程 度となる。基板を回転して反射光が最小となる角度に固

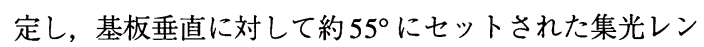
ズを用いて, サファイア基板の $\mathrm{Ag}$ 膜が堆積されている 側からラマン信号を集光し, 分光器で分光して液体窒素 で冷却された CCD で撮像した。露光時間は20４0分 で, 得られた像の宇宙線や残留放射線物質からの雑音を 消去した後, CCD ピクセルの縦列を加算してスペクト ルを得る。振動数の絶対值は基板サファイアからのラマ ン信号で補正し, クラスターの存在しない位置で得たス ペクトルをバックグランドとして差し引いた。

図3(a)に, 試料周辺の配置をさらに詳細に示す。こ の配置は Kretschmannの配置と呼ばれ, サファイア基板 の屈折率 $\left(n_{\mathrm{Al}_{2} \mathrm{O}_{3}}\right)$ とマトリクスの屈折率 $\left(n_{\text {matrix }}\right)$ の間に $n_{\mathrm{Al}_{2} \mathrm{O}_{3}}>n_{\text {matrix }}$ の関係があるときに, レーザーの入射角を 全反射(ATR : Attenuated Total Refrection)に調整する

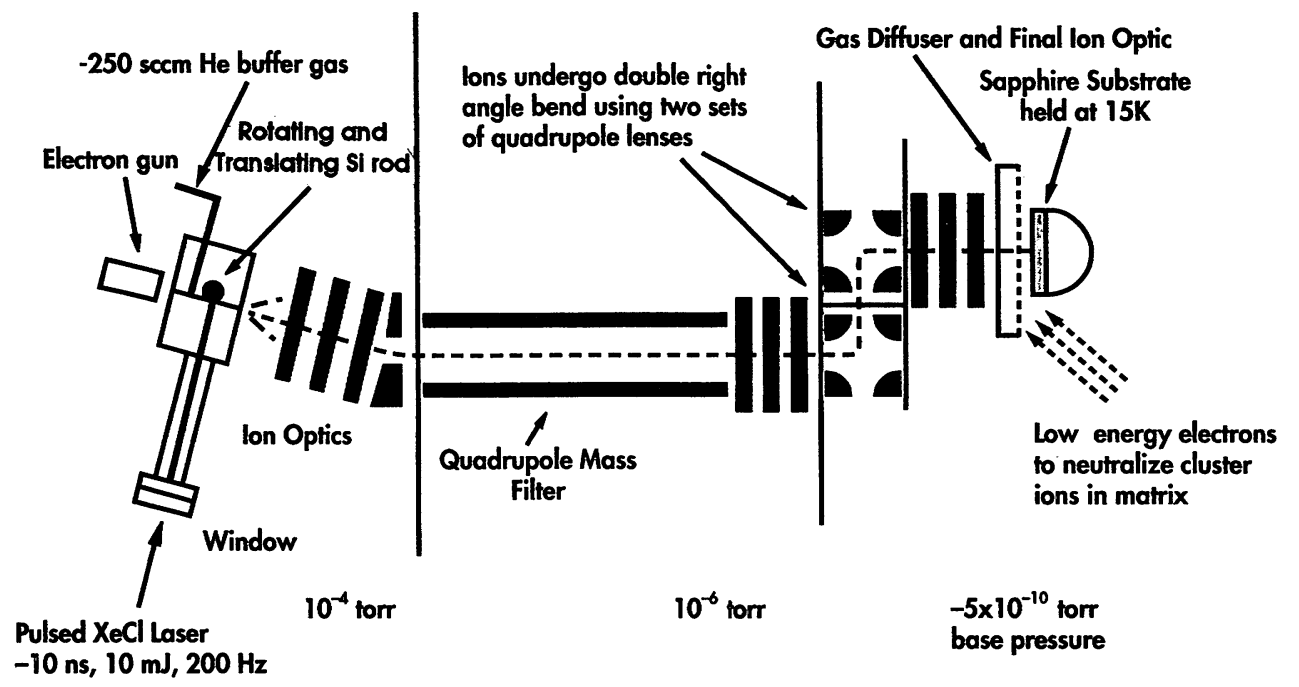

国 $1 \mathrm{Si}$ クラスター堆積・評価装置 


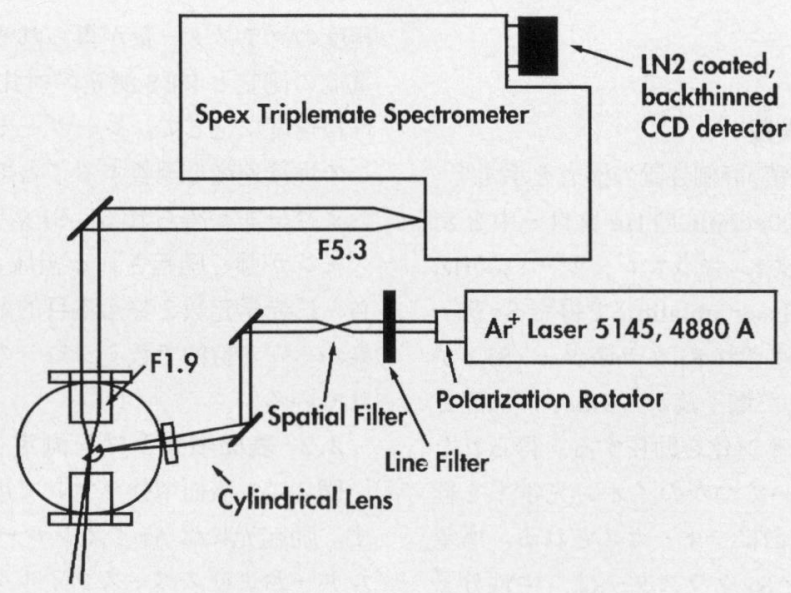

図 2 表面増強ラマン分光測定に用いた光学系

(a)

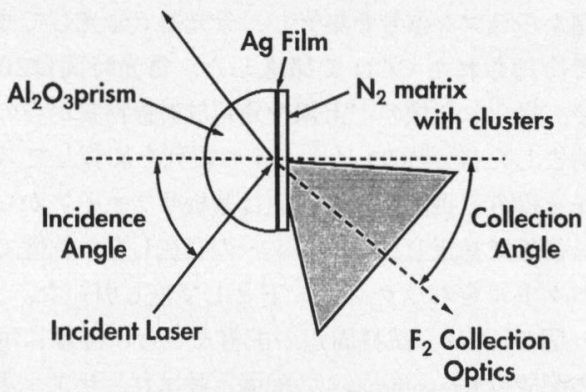

(b)

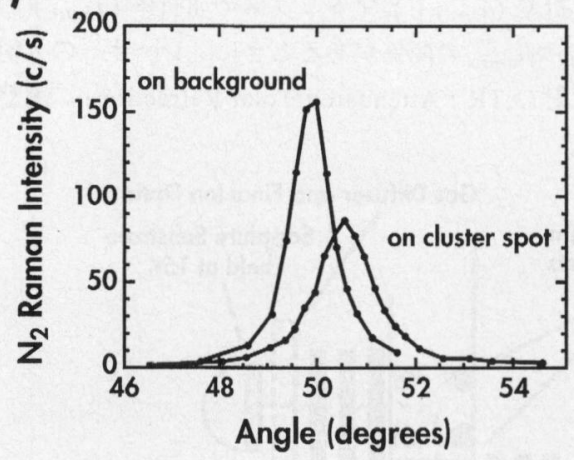

図 3 表面プラズモン一ポラリトン増強ラマンの配置と測 定例

(a)Kretschmann の配置，および (b) マトリクス $\mathrm{N}_{2}$ ラマン強度のレーザー入射角依存性

ことで, $\mathrm{Ag}$ の表面プラズモンが強く励起され, 基板温 度に $1 \sim 2{ }^{\circ} \mathrm{C}$ の上昇が見られた ${ }^{7)}$ 。励起される表面プラズ モンの電界ベクトルは Ag 膜表面に垂直で, その強度 は Ag 膜からの距離にしたがって指数関数的に減衰 $(1 / e=700 \AA)$ する。 図3(b)は， $\mathrm{N}_{2}$ をマトリクスとした際に，2328 $\mathrm{cm}^{-1} に$ 見られた固体 $\mathrm{N}_{2}$ からのラマン信号の強度と, レーザー 入射角との関係を示す。Si クラスターを含まない領域 (バックグランド) では，励起レーザーの入射角が49.5 $50^{\circ}$ のときにラマン信号強度が〜100倍に増強されてい る。このときに, レーザーの反射光は逆に大きく減衰 し，入射エネルギーのほとんどが表面プラズモンに転換 されたことを示す。 $\mathrm{Si}$ クラスターを約 $0.1 \%$ 含んだ領域 では, ラマン増強が得られるレーザー入射角が〜 $50.5^{\circ}$ にシフトし，ピーク幅が広がり信号増強効果も低下す る。これは, $\mathrm{Si}$ クラスターの存在が $\mathrm{N}_{2}$ マトリクスの屈 折率に影響を与えたためであり， $n_{\mathrm{N}_{2}}=1.273$ が $n_{\mathrm{N}_{2}}{ }^{\prime}=1.247$ に変化したと仮定すると, 実験結果をよく再現する フィッティングが得られた。実験的に最も強いラマン 増強は, $\mathrm{Ag}$ 膜を $200 \mathrm{~K} て ゙ 550 \AA$ 堆積し, 室温で数時間ア ニールすることで得られた。低温で堆積することで $\mathrm{Ag}$ の結晶粒成長が抑制され, 室温のアニールで膜中転位が 減少し表面平坦度が向上したと考えられる8)。

\section{3. 結果と考察}

\section{$3.1 \mathrm{Si}$ クラスターの構造解析}

図 4 (a), (b), (c)に，それぞれ $\mathrm{Si}_{4}, \mathrm{Si}_{6}$ および $\mathrm{Si}_{7}$ から 得たラマンスペクトルを示す ${ }^{9,10)}$ 。ab-initio 計算は, ま ず個々のサイズの Si クラスターに対していくつかの異 性体を仮定し, HF/6-3G* レベルで基底状態を決定し, さらにその構造とラマン活性な振動モードを MP2/6$31 G^{*}$ レベルで計算して, 実験的に得られたラマン振動 と比較した。図 5〜図7は,それぞれ $\mathrm{Si}_{4}, \mathrm{Si}_{6}$ および $\mathrm{Si}_{7}$ についてラマン振動の計算を行った基底構造 (各図 (a)), および比較の対象とした同異性体 (各図 (b) 以降) の構造 を示す。 

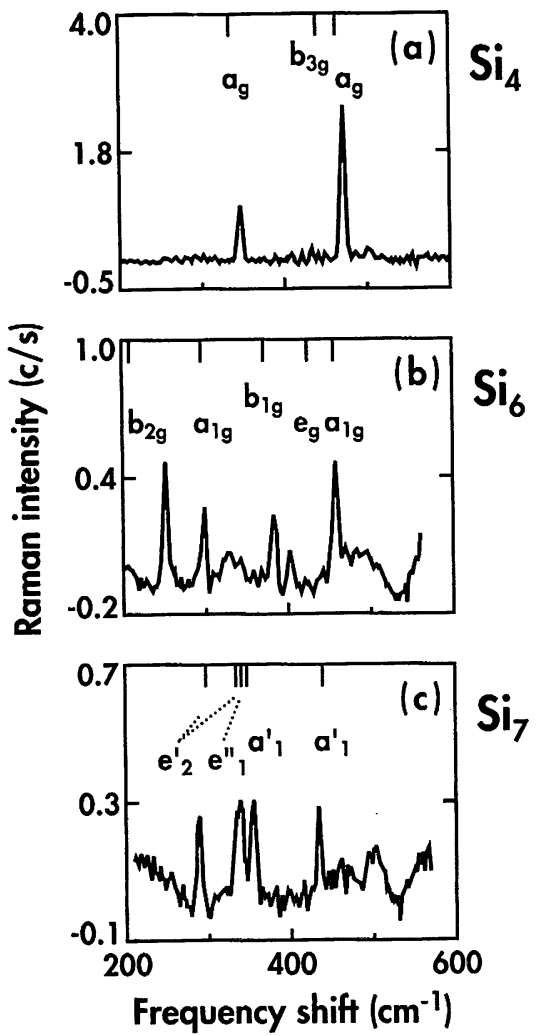

図 4 (a) $\mathrm{Si}_{4}$, (b) $\mathrm{Si}_{6}$ ，および (c) $\mathrm{Si}_{7}$ から得られたラマンスペ クトル

それぞれのクラスターは, $15 \mathrm{~K}$ 以下で $\mathrm{N}_{2}$ マトリクス 中に $0.1 \%$ 以下の濃度で堆積し, 同じ温度で測定した。 CCD を用いて $20 〜 40$ 分の露光で撮影したラマン像は, 残留放射物質などからの雑音を除去した後スペクトル に加工し, バックグランドを除去して,ささらにいくつ かのスペクトルを加算して，クラスターからの信号を 明瞭にした。計算から予想される振動モードの位置が 各図の上部にマークしてある

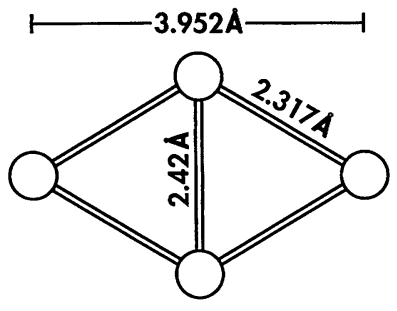

$\left(D_{2 h}\right)$

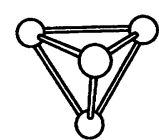

$\left(T_{d}\right)$ (a)

図 $5 \quad \mathrm{Si}_{4}$ の (a) 安定構造, および (b) 異性体

計算で得られた $\mathrm{Si}_{4}$ の安定構造は，全原子が同一平面に 存在する菱形状であり (図 5 (a)； $\mathrm{D}_{2 \mathrm{~h}}$ 対称)，そのラマン 活性な振動モードは $337\left(\mathrm{a}_{\mathrm{g}}\right), 440\left(\mathrm{~b}_{1 \mathrm{~g}}\right)$ および $463\left(\mathrm{a}_{\mathrm{g}}\right) \mathrm{cm}^{-1}$

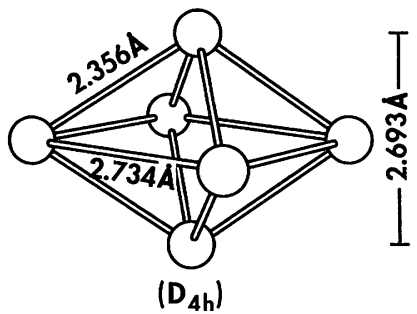

(a)

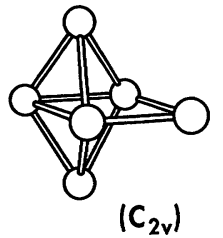

(b)

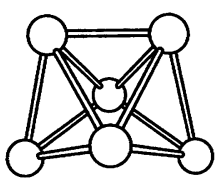

$\left(C_{2 v}\right)$

(c)

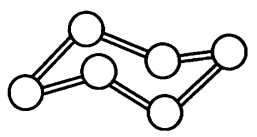

$\left(D_{3 d}\right)$

(d)
図6 $\mathrm{Si}_{6}$ の (a) 安定構造, および (b) (d) 異性体

と予測された。実際に観測されたピークは 345 および $470 \mathrm{~cm}^{-1}$ であり, 計算で求められた二つの $\mathrm{a}_{\mathrm{g}}$ モードと よく一致している。計算で予測された $b_{1 \mathrm{~g}}$ モードは，す ぐそばにある $\mathrm{a}_{\mathrm{g}}$ モードの $1 / 10$ の強度しかなく, サファ イア基板からのラマン信号にも近いためバックグランド に埋もれて，明暸に観察されなかったと考えられる。比 較のために計算した $\mathrm{T}_{\mathrm{d}}$ 構造 (図 5(b)) では，安定構造に 比べて $1 \mathrm{eV}$ 高いエネルギーをもつと計算され，予想され るラマンピークも，175, 195, 420, 499 および $648 \mathrm{~cm}^{-1}$ と，実験結果と大きく異なる。

$\mathrm{Si}_{6}$ の安定構造は，圧縮された 8 面体である (図6 (a); $\mathrm{D}_{4 \mathrm{~h}}$ 対称)。ab-initio 計算で得たエネルギー表面は浅 く, 圧縮の程度を決定することは難しい。しかしなが ら, 同じく圧縮された 8 面体である二つの $\mathrm{C}_{2 \mathrm{v}}$ 構造は いずれも $\left(\mathrm{D}_{4 \mathrm{~h}}\right)$ に収束した。この構造を基にラマン振動 を計算すると， 209( $\left.\mathrm{b}_{2 \mathrm{~g}}\right), 298\left(\mathrm{a}_{1 \mathrm{~g}}\right), 376\left(\mathrm{~b}_{1 \mathrm{~g}}\right), 425\left(\mathrm{e}_{\mathrm{g}}\right)$, $457\left(\mathrm{a}_{1 \mathrm{~g}}\right) \mathrm{cm}^{-1}$ となり, 実験結果 $252,300,386,404$, $458 \mathrm{~cm}^{-1}$ とよく一致する。なかでも， $\mathrm{b}_{2 \mathrm{~g}}$ と $\mathrm{e}_{\mathrm{g}}$ がそれぞ れ低波数側と高波数側にずれていることを除けば，計算 值と実験值の一致はたいへんに良好である。図に示した 構造の一部ボンド長があまりに長すぎる $(2.734 \AA ̊$ )こと を考慮すると，8面体の圧縮の程度が図よりも若干小さ いとすると $\mathrm{b}_{2 \mathrm{~g}}$ と $\mathrm{e}_{\mathrm{g}}$ モードが観測結果と一致する方向に シフトすると考えられる。 $\mathrm{Si}_{6}$ の異性体のもう一つの候 補である椅子型の 6 角形 (図 $6(\mathrm{~d}) ; \mathrm{D}_{3 \mathrm{~d}}$ 対称) は, 単結 晶から切り出すことの可能な構造であるが，203，324, $407 \mathrm{~cm}^{-1}$ に振動モードをもち，実駼結果と一致しない。

$\mathrm{Si}_{7}$ の安定構造は，上下に二つのキャップをもつ正 5 角形 (図 7 (a); $D_{5 h}$ 対称) と計算され，その振動モード 


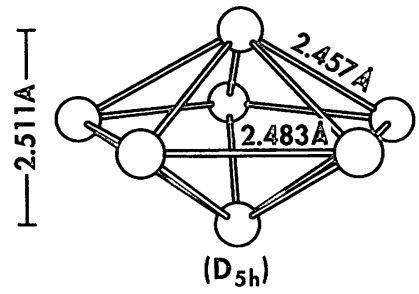

(ब)

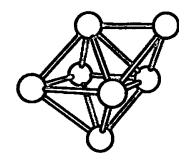

$\left(C_{3 v}\right)$

(c)

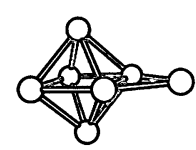

$\left(C_{2 v}\right)$

(ब)

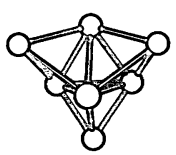

$\left(C_{3 v}\right)$

(b)

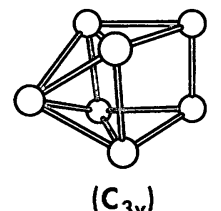

(e)
図 $7 \mathrm{Si}_{7}$ の (a) 安定構造，および (b) （e) 異性体

$300\left(\mathrm{e}_{2}\right), 339\left(\mathrm{e}_{2}\right), 346\left(\mathrm{e}^{\prime}{ }_{1}\right), 352\left(\mathrm{a}_{1}\right), 441\left(\mathrm{a}_{1}\right) \mathrm{cm}^{-1}$ と 予測された。実験結果は $289,340,358,435 \mathrm{~cm}^{-1}$ であ り，図 4(c) に見られる $340 \mathrm{~cm}^{-1}$ のピークが他のピーク より幅広であることから，二つ弱い振動モードの $\mathrm{e}_{2}{ }_{2}$ と $\mathrm{e}{ }_{1}$ が重なって観測されたと考えると実験結果と計算結 果の非常に良い一致が得られる。異性体の候補として考 えられる三つのキャップをもつ正 4 面体構造 (図 7 (b) ; $\mathrm{C}_{3 \mathrm{v}}$ 対称) は, 九つのラマン活性な振動をもち, 実験事 実と一致しない。また，他の異性体も図に比べて対称性 が低く多くのラマン振動を示し実験結果と食い違う。

以上実験結果と計算を比較した11本の振動に対する 差の平均は $10 \mathrm{~cm}^{-1}$ 以下であり，実験および計算の精度 を考慮すると，両者にきわめて良い一致が見られたと いってよい。したがって本実験により， $\mathrm{Si}_{4}$ と $\mathrm{Si}_{6}$ および $\mathrm{Si}_{7}$ に関して，その構造が決定されたと考える。また， 本実験の範囲では，マトリクス材料を変えたことによる ラマンスペクトルの変化は見られず，ここで得られた構 造は,マトリクスの影響を受けたとは考えられない。さ らに，残留酸素や水素が Si クラスターの構造に影響を 与えていないことは, $\mathrm{Si}-\mathrm{H}$ や Si-O の振動モードに対応 するラマンピークが存在しないことで確認した。

\subsection{Si クラスターの疑集}

図4に示したラマンスペクトルは，すべてマトリクス 中のクラスター密度が $0.1 \%$ (Vol.) 以下の条件で得たが，ク ラスターの密度を大きくすると別の特徴的な構造が現れ る。図 8 は, 密度 $0.3 \%$ 程度で堆積した $\mathrm{Si}_{6}$ の堆積直後 (図 $8(\mathrm{a})$ ) と,さまざまなアニール処理後のラマンスペ クトルを示す。

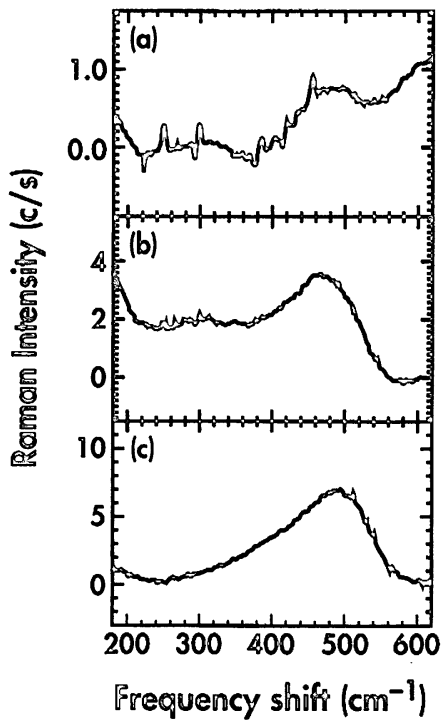

図 $8 \mathrm{Si}_{6}$ を出発材料としたクラスターの凝集過程 (a) 堆積直後, (b) 30K 10時間アニール 後, (c) “軟着陸” 後

堆積直後のラマンスペクトルには，図 4 (b) で見たの と同じ位置に $\mathrm{Si}_{6}$ クラスターに起因するシャープなピー クが見られると同時に，バックグランドにブロードな二 つのピークが存在する。このブロードなピークは $\mathrm{Si}_{6}$ ク ラスターが凝集してできた相(以下便宜的に“凝集クラス ター”と呼ぶ）と考えられ，特定の製法で作製した非晶 質 Si からのラマン信号に類似している11)。クラスター 密度とマトリクスの温度 (15K 程度) を考慮すると，二 つを大きく越える $\mathrm{Si}_{6}$ クラスターが凝集したとは考えに くく, 少数の $\mathrm{Si}_{6}$ クラスターが凝集することで, $\mathrm{Si}_{12}$ や $\mathrm{Si}_{18}$ に対応するシャープなピークではなく，非晶質 $\mathrm{Si}$ に 類似したラマン信号を示したことは興味深い。また，期 待される凝集クラスターの量に比べて, $\mathrm{Si}_{6}$ のピークに 対するブロードなピークの強度が大きく，凝集クラス ターのラマン断面積が大きいことが予想される。

つぎに，連続供給している液体 $\mathrm{He}$ の流量を調整する ことで，試料温度を $28 \sim 30 \mathrm{~K}$ に昇温し10時間程度のア ニールを行うと, 図 8 (b) に示すようにシャープなピー クは消えて, ブロードなピークのみが残りその強度が増 加した。このアニール温度は，マトリクスに用いた $\mathrm{N}_{2}$ の 3 重点の $1 / 3$ 程度であり，低温高速で堆積した固体 $\mathrm{N}_{2}$ は結晶性に劣る多孔質状であると考えられるので, $\mathrm{Si}$ ク ラスターがマトリクス中を拡散・移動して凝集が加速さ れたと考えられる。図 8 (c) は，さらに試料温度を上昇 し $(60 \mathrm{~K}$ 程度) マトリクスを蒸発させて, Si クラスター を $\mathrm{Ag}$ 上に“軟着陸”した後に，再び $\mathrm{N}_{2}$ マトリクスを堆 
積して得たラマンスペクトルである。図 $8(b)$ に見たブ ロードな二つのピークは消えて, よりブロードでピーク 位置のシフトしたラマン信号が見られる。このスペクト ルも，前述のものとは異なった製法で得た非晶質 Si に よく見られる特徵的なスペクトルである。

図8の (a)から (c) は Si クラスターを出発材料として, 非晶質 Si の形成過程をトレースしたと考えることがで きる。 $\mathrm{Si}_{4} や \mathrm{Si}_{7}$ を出発材料としても同様の過程が見ら れ，一般的にクラスターを出発材料としてその凝集過程 を追うことで, 従来より議論のある非晶質 $\mathrm{Si}$ の構造に 関して，そのヒントを得ることができるのではないかと 期待される。

\section{4. むすび}

以上，作製した Si クラスターを質量分離し，マトリ クスに埋め込むことで，物理的な評価に十分な物理量を 確保することが可能となった。本稿では，ラマン分光法 を用いた構造決定を行ったが，同じ配置を用いてフォト ルミネセンスの測定も比較的容易に行うことが可能であ る。さらに, 従来困難であったさまざまな評価を組合 せ，本稿で取り上げることのできなかったもっとサイズ の大きなクラスターを含めて，その構造や物理的性質の 解明が進み, クラスター領域に対する理解が飛躍的に深 まることが期待される。

\section{文献}

1) W. L. Brown, R. R. Freeman and K. Raghavachari : Science 235, 865 (1987).

2) M. F. Jarrold : Science 252, 1085 (1991).

3) M. F. Jarrold, Y. Ijiri and U. Ray : J. Chem. Phys. 94, 3607 (1991).

4) M. F. Jarrold and V. Constant : Phys. Rev. Lett. 67, 2994 (1991).

5) M. F. Jarrold and E. C. Honea : J. Phys. Chem. 95, 9181 (1986).

6) J. E. Bower and M. F. Jarrold : J. Chem. Phys. 97, 8312 (1992).

7) E. Kretschmann : Z. Phys. 241, 313 (1971).

8) M. D. Tillin and J. R. Sambles : J. Mod. Opt. 38, 731 (1991).

9) E. C. Honea, A. Ogura, C. A. Murray, K. Raghavachari, W. O. Sprenger, M. F. Jarrold and W. L. Brown : Nature 366, 42 (1993).

10) A. Ogura, E. C. Honea, C. A. Murray, K. Raghavachari, W. O. Sprenger, M. F. Jarrold and W. L. Brown : Mat. Res. Soc. Symp. 332, 333 (1994).

11) S. Roodra, W. C. Sinke, J. M. Poate, D. C. Yacobson, S. Dierker, B. S. Dennis, D. J. Eaglesham, F. Spaepen and P. Fuoss : Phys. Rev. B 44, 3702 (1991). 